\title{
Would Liberalization Lead to Epidemic Cocaine Consumption?
}

\author{
Norman V. Loayza \\ Naotaka Sugawara \\ The World Bank \\ The World Bank
}

August 2011

\begin{abstract}
This paper uses cross-country data to estimate the potential effect of drastic reductions in the price of cocaine on the share of the population who consumes this drug. In order to identify movements along the cocaine consumption/demand function, the paper instruments for cocaine prices with variables that affect the supply of cocaine. Liberalization of drug policies would produce an increase in the prevalence of cocaine consumption. However, the quantitative evidence presented here suggests that, even if substantial, this increase would not amount to epidemic cocaine use.
\end{abstract}

JEL: $I 18, K 42$

Keywords: Drug Liberalization, Drug Prohibition, Cocaine Consumption

* We are grateful to Ximena Del Carpio, Phil Keefer, Peter Reuter, and Rodrigo Soares for valuable insights. The findings and conclusions expressed in the paper are entirely those of the authors. They do not necessarily represent the views of the World Bank, its directors, or the governments they represent. 


\section{Introduction}

The prohibition of the drug trade has triggered a long train of unintended negative consequences, especially for developing countries. The most detrimental of them are violence and organized crime, along with the political and social instability they can unleash (see Kugler, Verdier, and Zenou, 2005). This has prompted ever increasing calls for a paradigm change in drug policies, away from prohibition and criminalization and towards public health and education (see Cardoso, Gaviria, and Zedillo, 2009).

Not surprisingly, these calls have encountered considerable resistance. Arguably the most important objection to any drug-liberalization attempt stems from the fear that it may bring about an epidemic increase in drug use. Since consumption is already legal or lightly punished in the majority of countries, the potential increase in drug use would result from the sharp decrease in prices that liberalization would entail. In fact, Miron (2003) and Grossman (2004) estimate that the price of cocaine in the U.S. would drop by 50 to 80 percent in a legalized market.

What would be the effect of such a large price decrease on cocaine consumption, and particularly on the share of the population that use this drug? Most of the existing studies are only partially helpful in answering this question because they are designed to quantify drug demand elasticities for small price changes (MacCoun and Reuter, 2001; and Mejía and Posada, 2010). Moreover, they focus on the price effect on the consumption of existing drug users.

Focusing on the case of cocaine, this paper seeks to contribute to this debate by using cross-country data to estimate the potential effect of sharp price changes on the share of the population who uses drugs. The estimation of "arc" elasticities (that is, elasticities over large price changes) is possible in this context because cross-country data exhibits substantial variation in cocaine prices. We have made every effort to detect and eliminate data mismeasurement but acknowledge that it is a problem with cross-country information. The macro evidence presented here is only intended as complementary to the micro evidence already available.

\section{Data and Methodology}

Our empirical analysis exploits the cross-country variation of the data. Using the data sources described in the appendix, the final sample consists of 58 countries, with data averaged over the period 2000-2007. ${ }^{1}$ The empirical model can be summarized as follows,

$$
\operatorname{CocCons}_{i}=\beta_{0}+\beta_{1} \operatorname{CocPric}_{i}+\beta_{2} X_{i}+\varepsilon_{i}
$$

\footnotetext{
${ }^{1}$ The scarcity of data in the time-series dimension prevents us from using panel-data techniques.
} 
Where the subscript $i$ represents country; CocCons denotes the cocaine consumption prevalence rate (that is, the share of the population that uses cocaine); CocPric is the cocaine retail price per gram (in logs); and $X$ is a set of additional potential determinants of cocaine consumption prevalence. This set includes the $(\log )$ prices of heroin and marijuana, as potential complements or substitutes of cocaine; (log) GDP per capita, as a measure of average income; and the urbanization rate, as an indicator of demographic development.

Table 1. Summary statistics

\begin{tabular}{|c|c|c|c|c|c|c|}
\hline & $\mathrm{N}$ & Mean & Median & $\begin{array}{l}\text { Std. } \\
\text { Dev. }\end{array}$ & Min & Max \\
\hline $\begin{array}{l}\text { Cocaine consumption (\% of population } \\
\text { aged } 15-64 \text { ) }\end{array}$ & 58 & 0.700 & 0.625 & 0.641 & 0.002 & 2.825 \\
\hline $\begin{array}{l}\text { Cocaine retail prices (constant } 2005 \\
\text { US\$ per gram) }\end{array}$ & 58 & 80.976 & 74.020 & 57.100 & 1.827 & 297.079 \\
\hline $\begin{array}{l}\text { Heroin retail prices (constant } 2005 \text { US\$ } \\
\text { per gram) }\end{array}$ & 58 & 94.010 & 55.303 & 114.558 & 12.699 & 733.254 \\
\hline $\begin{array}{l}\text { Marijuana retail prices (constant } 2005 \\
\text { US\$ per gram) }\end{array}$ & 58 & 7.438 & 5.866 & 8.505 & 0.109 & 53.454 \\
\hline $\begin{array}{l}\text { GDP per capita (PPP, constant } 2005 \\
\text { int'l \$, in logs) }\end{array}$ & 58 & 9.550 & 9.654 & 0.860 & 7.400 & 11.147 \\
\hline $\begin{array}{l}\text { Urban population (\% of total } \\
\text { population) }\end{array}$ & 58 & 69.226 & 67.535 & 15.675 & 31.978 & 100.000 \\
\hline Cocaine seizures (\% of world total) & 58 & 1.496 & 0.013 & 5.023 & 0.000 & 28.477 \\
\hline $\begin{array}{l}\text { Cocaine producer countries (dummy } \\
\text { variable) }\end{array}$ & 58 & 0.052 & 0.000 & 0.223 & 0.000 & 1.000 \\
\hline $\begin{array}{l}\text { Police personnel (per 100,000 } \\
\text { population, in logs) }\end{array}$ & 58 & 5.633 & 5.700 & 0.530 & 2.731 & 6.392 \\
\hline
\end{tabular}

Source: Authors' calculation from data sources described in the appendix.

The regression model is formulated in the spirit of a demand function, with the caveat that cocaine consumption prevalence is more directly an indicator of number of consumers rather than total quantity demanded. The main econometric challenge in this demand-like specification is that the cocaine price, in all likelihood, is jointly endogenous. Following the logic of supply and demand functions, we can select viable instrumental variables from among the determinants of the supply of cocaine in order to identify movements along the consumption/demand function. The proposed instruments are the following: an

\footnotetext{
2 In robustness exercises (available upon request), we consider other potential determinants of cocaine consumption prevalence, such as the share of young population, the rate of alcohol consumption, and, most importantly, the degree of cocaine retail purity. They were not significantly related to cocaine consumption prevalence, and their inclusion did not affect the coefficient on cocaine price to any important extent. Given these facts and their limited data availability (which in the last two cases reduced the sample size considerably), we decided to exclude them from the basic specification.
} 
indicator of cocaine production, i.e., a dummy variable that denotes whether the country is a major cocaine producer; a proxy of cocaine trafficking, i.e., the country's cocaine seizures as percentage of the world total; and an indicator of enforcement strength, i.e., police personnel per capita in the country. Table 1 presents summary statistics of the main regression variables and the instrumental variables.

\section{Results}

The empirical model for cocaine consumption prevalence is estimated through a Two Stage Least Squares (IV) procedure. Table 2 presents the results of the IV's first-stage regression, by which we check whether the instrumental variables have reasonable explanatory ability on cocaine prices, the jointly endogenous variable.

\section{Table 2. First-stage regression}

\begin{tabular}{lc}
\hline $\begin{array}{l}\text { Dependent variable: Cocaine retail prices (constant } \\
\text { per gram, in logs) }\end{array}$ & IV \\
\hline & [First-stage] \\
\hline Heroin retail prices & $0.489^{* * *}$ \\
(constant 2005 US\$ per gram, in logs) & 3.06 \\
Marijuana retail prices & 0.180 \\
(constant 2005 US\$ per gram, in logs) & 1.22 \\
GDP per capita & 0.250 \\
(PPP, constant 2005 international \$, in logs) & 1.19 \\
Urban population & -0.005 \\
(\% of total population) & -0.83 \\
Cocaine seizures & $-0.035^{* *}$ \\
(\% of world total) & -2.03 \\
Cocaine producer countries & $-0.989^{* *}$ \\
(dummy: 1 if coca leaf production is reported) & -2.24 \\
Police personnel & $0.267 *$ \\
(per 100,000 population, in logs) & 1.96 \\
Constant & -1.691 \\
& -0.92 \\
\hline Number of observations & 58 \\
Kleibergen-Paap rk LM test (p-value) & 0.67 \\
\hline Source: Authors' estmation & 0.05 \\
\hline
\end{tabular}

Source: Authors' estimation.

Notes: Heteroskedasticity-robust z-statistics are presented below the corresponding coefficients. $*, * *$, and $* * *$ denote significance at the 10 percent, 5 percent, and 1 percent levels, respectively. Variables are averages of 2000-2007 by country. See the appendix for definitions and sources of variables. 
The three instrumental variables carry statistically significant coefficients of expected signs: cocaine seizures and cocaine production, as indicators of drug availability in the country, are negatively related to cocaine price; and police personnel, as indicator of enforcement strength, is positively related. In accordance with this, the Kleibergen-Paap test rejects the null hypothesis of under-identification of the instrumental variables.

Table 3. Explaining cocaine consumption prevalence

Dependent variable: Cocaine consumption (\% of population aged 15-64)

\begin{tabular}{lcc}
\hline & {$[1]$} & {$[2]$} \\
& OLS & IV \\
\hline Cocaine retail prices & $-0.366^{* * *}$ & $-0.663^{* *}$ \\
(constant 2005 US\$ per gram, in logs) & -5.50 & -2.05 \\
Heroin retail prices & $0.245^{* * *}$ & $0.405^{* *}$ \\
(constant 2005 US\$ per gram, in logs) & 3.16 & 2.02 \\
Marijuana retail prices & -0.091 & 0.005 \\
(constant 2005 US\$ per gram, in logs) & -1.08 & 0.03 \\
& & \\
GDP per capita & $0.441^{* * *}$ & $0.512^{* * *}$ \\
(PPP, constant 2005 international \$, in logs) & 3.63 & 3.10 \\
& & \\
Urban population & 0.003 & -0.001 \\
(\% of total population) & 0.56 & -0.14 \\
Constant & & \\
& $-3.134 * * *$ & $-3.155^{* * *}$ \\
\hline Number of observations & -2.95 & -2.61 \\
$\mathrm{R}^{2}$ (centered) & 58 & 58 \\
Hansen J test (p-value) & 0.34 & 0.23 \\
\hline Source: Authorstiman & - & 0.51 \\
\hline
\end{tabular}

Source: Authors' estimation.

Notes: Heteroskedasticity-robust $\mathrm{t}(\mathrm{z})$-statistics are presented below the corresponding coefficients. $* *$ and $* * *$ denote significance at the 5 percent and 1 percent levels, respectively. For IV regression [2], endogenous variable is cocaine retail prices and instruments are cocaine seizures, cocaine producer countries, and police personnel. Variables are averages of 2000-2007 by country. See the appendix for definitions and sources of variables.

Table 3 presents the main results of the paper. ${ }^{3}$ Column 2 shows the IV's twostage regression results, and for comparison purposes, column 1 shows the results obtained with Ordinary Least Squares (OLS). The Hansen $J$ test of overidentifying restrictions appears to support the validity of the instruments. It does

${ }^{3}$ Following up on robustness exercises (available on request), the results are qualitatively similar if the main producers of cocaine-Bolivia, Colombia, and Peru-are excluded from the sample. 
not reject the null hypothesis of zero correlation between the instrumental variables and the error term, suggesting that the exclusion restrictions are likely to hold.

Cocaine consumption prevalence is responsive to price changes. Most importantly, it rises as its own price decreases: the coefficient on cocaine retail prices is negative and statistically significant. The point estimate under IV is about $80 \%$ larger in magnitude than under OLS. This is consistent with the fact that OLS renders a downward bias (in absolute value) in the estimated price elasticity of consumption/demand when price movements are not only due to exogenous supply shifts.

Cocaine consumption prevalence is also responsive to heroine prices, with a positive and statistically significant coefficient that suggests substitutability between cocaine and heroin. No similar relationship appears to exist between cocaine and marijuana. Finally, the results indicate that the prevalence of cocaine consumption is larger in countries with higher per capita income, suggesting cocaine as a normal good.

By how much would cocaine consumption prevalence increase if cocaine prices were to drop? We can use the corresponding estimated coefficient from the IV regression to provide an approximate, albeit rough, answer. If cocaine prices were to drop by $80 \%$ in the United States (i.e., the upper-bound under liberalization according to the studies cited above), the country's cocaine consumption prevalence would increase by about 1.1 percent of the population (nearly $40 \%$ of its current level).

The regression results can be used for further quantitative explorations. If cocaine prices were to decrease from the 75th percentile of their distribution (around $\$ 95$ per gram, in Austria and Sweden) to the 25th percentile (around \$20 per gram, in Costa Rica and El Salvador) then the prevalence of cocaine consumption would increase by approximately 1 percent of the population. Using a more drastic change in cocaine prices from the 90th to the 10th percentile of the distribution (e.g., from Finland and Norway to Jamaica and Bolivia), the increase in the prevalence of cocaine consumption would be about 2 percent of the population. ${ }^{4}$

\section{Conclusion}

Liberalization of drug policies --to the extent that it leads to a drastic decrease in cocaine prices-- would produce an increase in the prevalence of cocaine consumption. However, the quantitative evidence presented here suggests that, even if substantial, this increase would not amount to widespread or epidemic cocaine use. Our analysis rests on the comparative experiences of countries with

\footnotetext{
${ }^{4}$ For comparison purposes, note that the world mean and standard deviation of cocaine consumption prevalence are 0.7 percent and 0.64 percent of the population, respectively.
} 
marked differences in cocaine prices; and our conclusion is likely derived from the fact that even in countries where cocaine prices are quite low, cocaine is not widely consumed. A self-restraining societal mechanism --more important than drug prohibition or other price-increasing strategy-- may already be at play.

\section{References}

Cardoso, Fernando Henrique, César Gaviria, and Ernesto Zedillo (2009). "The War on Drugs is a Failure," Wall Street Journal, Feb. 23, 2009.

Grossman, Michael (2004). "Individual Behaviors and Substance Use: The Role of Prices.” NBER Working Paper 10948.

Kugler, Maurice, Thierry Verdier, and Yves Zenou (2005). "Organized Crime, Corruption and Punishment." Journal of Public Economics 89 (9/10): 1639-1663.

Mejía, Daniel and Carlos E. Posada (2010). "Cocaine Production and Trafficking: What Do We Know?" In Innocent Bystanders: Developing Countries and the War on Drugs, ed. Philip Keefer and Norman Loayza. Washington DC: Palgrave Macmillan and The World Bank.

MacCoun, Robert and Peter Reuter (2001). Drug War Heresies: Learning from Other Vices, Times and Places. New York: Cambridge University Press.

Miron, Jeffrey (2003). "Do Prohibitions Raise Prices: Evidence from the Market for Cocaine." Review of Economics and Statistics 85 (3): 522-530.

UNODC (United Nations Office on Drugs and Crime). World Drug Report. New York City, NY.

UNODC. United Nations Surveys on Crime Trends and the Operations of Criminal Justice Systems. http://www.unodc.org/unodc/en/data-andanalysis/United-Nations-Surveys-on-Crime-Trends-and-the-Operationsof-Criminal-Justice-Systems.html

World Bank. World Development Indicators. http://data.worldbank.org/datacatalog/world-development-indicators 


\section{Appendix. Definitions and sources of variables}

\begin{tabular}{|c|c|c|}
\hline Variable & Definition and construction & Source \\
\hline $\begin{array}{l}\text { Cocaine } \\
\text { consumption }\end{array}$ & $\begin{array}{l}\text { Prevalence of abuse of cocaine as percentage of } \\
\text { the population aged } 15-64 \text {. }\end{array}$ & $\begin{array}{l}\text { World Drug Report } \\
\text { (UNODC). }\end{array}$ \\
\hline $\begin{array}{l}\text { Cocaine retail } \\
\text { prices }\end{array}$ & $\begin{array}{l}\text { Typical retail (street) prices of cocaine expressed } \\
\text { in the constant } 2005 \text { US\$ per gram, in logs. The } \\
\text { Consumer Price Index (CPI) is used to deflate the } \\
\text { series. Prices of crack cocaine are not included. } \\
\text { Prices of coca base are also ignored unless no } \\
\text { other price data are available. }\end{array}$ & $\begin{array}{l}\text { World Drug Report, and } \\
\text { World Development } \\
\text { Indicators (World Bank). }\end{array}$ \\
\hline $\begin{array}{l}\text { Heroin retail } \\
\text { prices }\end{array}$ & $\begin{array}{l}\text { Typical retail (street) prices of heroin expressed } \\
\text { in the constant } 2005 \text { US\$ per gram, in logs. The } \\
\text { CPI is used to deflate. Prices of black tar and } \\
\text { homebake heroin are excluded. When multiple } \\
\text { prices are available (for most cases, those of } \\
\text { heroin no. } 3 \text { and no.4), a simple average is } \\
\text { computed. }\end{array}$ & $\begin{array}{l}\text { World Drug Report, and } \\
\text { World Development } \\
\text { Indicators. }\end{array}$ \\
\hline $\begin{array}{l}\text { Marijuana retail } \\
\text { prices }\end{array}$ & $\begin{array}{l}\text { Typical retail (street) prices of marijuana } \\
\text { (cannabis herb) expressed in the constant } 2005 \\
\text { US\$ per gram, in logs. The CPI is used to deflate. }\end{array}$ & $\begin{array}{l}\text { World Drug Report, and } \\
\text { World Development } \\
\text { Indicators. }\end{array}$ \\
\hline GDP per capita & $\begin{array}{l}\text { PPP-adjusted real GDP per capita (2005 } \\
\text { international \$), in logs. }\end{array}$ & $\begin{array}{l}\text { World Development } \\
\text { Indicators, and Penn } \\
\text { World Table } 6.3 \text { (Heston, } \\
\text { Summers, and Aten, } \\
\text { 2009). }\end{array}$ \\
\hline $\begin{array}{l}\text { Urban } \\
\text { population }\end{array}$ & $\begin{array}{l}\text { Percentage of the total population living in urban } \\
\text { agglomerations. }\end{array}$ & $\begin{array}{l}\text { World Development } \\
\text { Indicators. }\end{array}$ \\
\hline Cocaine seizures & $\begin{array}{l}\text { Seizures of cocaine (base and salts), as a share of } \\
\text { world total. }\end{array}$ & World Drug Report. \\
\hline $\begin{array}{l}\text { Cocaine } \\
\text { producer } \\
\text { countries }\end{array}$ & $\begin{array}{l}\text { A dummy variable for countries where production } \\
\text { of coca leaf is reported in any year during } 2000 \text { to } \\
\text { 2007. The following three countries fall in this } \\
\text { category: Bolivia, Colombia and Peru. }\end{array}$ & $\begin{array}{l}\text { International Narcotics } \\
\text { Control Strategy Report } \\
\text { (United States } \\
\text { Department of States). }\end{array}$ \\
\hline Police personnel & $\begin{array}{l}\text { Number of police personnel per } 100,000 \\
\text { population, expressed in logs. }\end{array}$ & $\begin{array}{l}\text { United Nations Surveys } \\
\text { on Crime Trends and the } \\
\text { Operations of Criminal } \\
\text { Justice Systems } \\
\text { (UNODC). }\end{array}$ \\
\hline
\end{tabular}

